\title{
Social Media as a Student Career Selection Preference
}

\author{
$1^{\text {st }}$ Edris Zamroni ${ }^{1}, 2^{\text {nd }}$ Nur Mahardika $^{2}, 3^{\text {rd }}$ Susilo Rahardjo ${ }^{3}, 4^{\text {th }}$ Masturi $^{4}$ \\ \{edris.zamroni@umk.ac.id ${ }^{1}$,nur.mahardika@umk.ac.id², susilo.rahardjo@umk.ac.id², \\ masturi@umk.ac.id ${ }^{4}$ s\}
}

Universitas Muria Kudus, Kudus, Indonesia ${ }^{1,2,3,4}$

\begin{abstract}
The lives of the majority of students are currently absorbed by activities in social media such as Facebook, Instagram, WhatsApp, Twitter, and the others that allow a wide variety of both positive and negative information for the development in life and career selection activities. The purpose of this study is to find out how much the preference or tendency for students to use social media as a media literacy in career selection is. This article will reveal important data on the role of social media in influencing a student's career decision making. The research method used was a multistage random sampling technique involving 250 students from vocational high schools in Kudus Regency. The results of this study indicate that $61 \%$ of students use social media to find information that is used to consider advanced career selection. Meanwhile, the rest $12 \%$ chose a career based on their understanding of talent, $14 \%$ chose a career because of the opinions from parents or siblings, and 13\% followed their friends and closest friends. This shows that social media have a significant role in helping students determine the future of their careers.
\end{abstract}

Keywords: social media, career selection preference

\section{Introduction}

Career decision-making process is the culmination of important sequences in one's career development. Students in general have been required to be able to choose suitable careers since the tenth grade of senior/vocational high school[1]. In the development process, career selection process is strongly affected by internal and external factors of an individual. Different combinations of these factors interact one another from time to time to result in different decisions. Educational or occupational preferences, for example, are considered as a result of evaluative self-observation based on learning experiences related to career assignments and can be modified by further environmental events and social learning [2].

In career selection process, students try to explore information from variousaccessible resources. It is widely accepted that career selection process is also influenced by aspects of students' socialization with the surrounding environment and students' social structure as well as social structure in the environment around them [3]. In addition, family relationships and students' lifestyle are also considered influential in the career selection process that they carried out [4]. Later it was also identified that emotional intelligence also influences career decision-making and selection processes at least in terms of possessed values, interests and career aspirations [5]. 
The development of technology allows students to obtain information from different directions without being limited by space and time. The educational development also leads to the use of technology that allows students to access learning information directly from their own hands. Information obtained by students through their gadgets will have the tendency to influence the aspirational development of education, career expectations and self-efficacy in choosing their careers [6]. Preliminary information is important for future career development of students because research shows a significant retention of career choice identities at the beginning of the study period with their learning experiences and interventions provided for the development of information about their careers [7].

Data shows that there are 130 million social media users domiciling in Indonesia [8]. Another fact also shows that the average Indonesian persons use social media for 51 minutes. This information shows that social media have a large portion of time to grab people's attention. While surfing on social media,there is a high possibility for someone to get information about opportunities for work, higher education to information about strategies to achieve life success that are important for one's career development. Such information will affect their motivation and perception in determining their career choices [9]. Despite the availability of various motivations and interests in choosing a career, determining career choicesis also highly influenced by the stereotypical view of gender roles in available career choices [10].

Research on students' preferences in choosing careers with the situation where social media dominate the life of human is important to do so that the information on how students determine their career choices can be obtained. This is in accordance with the findings mentioning that the issue of obtained information regarding the availability of scholarships, the interaction of lecturers with prospective students and the possibility of potential development for personal benefits that can be obtained through social media influences career choices of students in South Africa [11]. However, someone who will be a graduate of either high school or higher education must wisely choose a career choice that is measurable which can be done by getting objective and reliable information [12]. There have been previously conducted researches that direct the use of internet media to provide important information about career development and enable direct interaction of the process of handling career barriers in the counseling process [13].

To date, there areno studies revealing the role of social media in students' career selection process. This article will revealthe way students determine their preferences in choosing their careers, especially on how social media interventions influence their career selection process through the interaction and available information. Furthermore, it also describes other strategies used by students in determining their career choices such as using parents as a guideline, using friendship network as a source of information, and understanding their talents and interests in determining career choices. The implication is that it is expected that the formulation of career guidance service programs can facilitate students' interest in the use of social media and support the counselor's efforts in helping students to understand their talents and interests in choosing a career. This especially applies in the process of developing technology-based programs that allow students to obtain comprehensive information about talents, interests and information on career opportunities without any space and time limitations. 


\section{Methods}

This study collected information about social media preferences in students' careers choices. The population chosen was 27,875 students [14] from 82 schools [15]whichwere then clustered to select the schools considered to have different characteristics from their accreditation levels. The datasets of this study are accessible inhttps://osf.io/bu6dz/ and the instrument of this study is accessible inhttps://osf.io/5ntuk/[16]. The instrument appreciated 12 items that had been validated by 5 (five) career guidance experts from 4 (four) state university and private university in Central Java and East Java. The validation process was approved in the construct and approved items for disclosing data. Find instruments are stated to be good (scoring 4.2 out of 5) and can reveal student career selection references. The results were selected 7 accredited "C"schools, 8 accredited"B" schools and 10 accredited "A" schools with a total of 25 schools. The selection process based on accreditation was in accordance with the ability of each school to provide supporting facilities for the use of social media and internet connection, and the characteristics of the social structure of each school. Accreditation that reflects the quality of the school also indicates the input of students and the social background of students, especially in the fulfillment of learning facilities by parents, including ownership of gadgets and social media accounts of each student. Then a survey was conducted on 250 students from 25 senior and vocational schools, both public and private ones, in Kudus Regency. Respondents of this study ranged between 14-18 years.Each school was represented by 10 students as a randomly selected sample for classes X, XI and XII.

\section{Result}

Students have the potential to obtain constructive and destructive information. This study assumes the positive benefits of social media in providing additional information about career choices that students can take regarding either college, work, or family life.In general, the results of the survey obtained data as shown in table1. Based on table 1, the information shows that $61 \%$ of students use social media as a consideration for choosing higher education and job choices, $12 \%$ of students choose their careers based on understanding their talents and interests, $14 \%$ choose a career based on suggestionsfrom parents and relatives, and 13\% choose a career based on a choice of friends or close friends.In detail, career choice preferences are formed by 12 choice patterns. In general, the 12 choice patterns in question can be observed in datasets which can be accessed on https://osf.io/6rf5k/and figure 1.

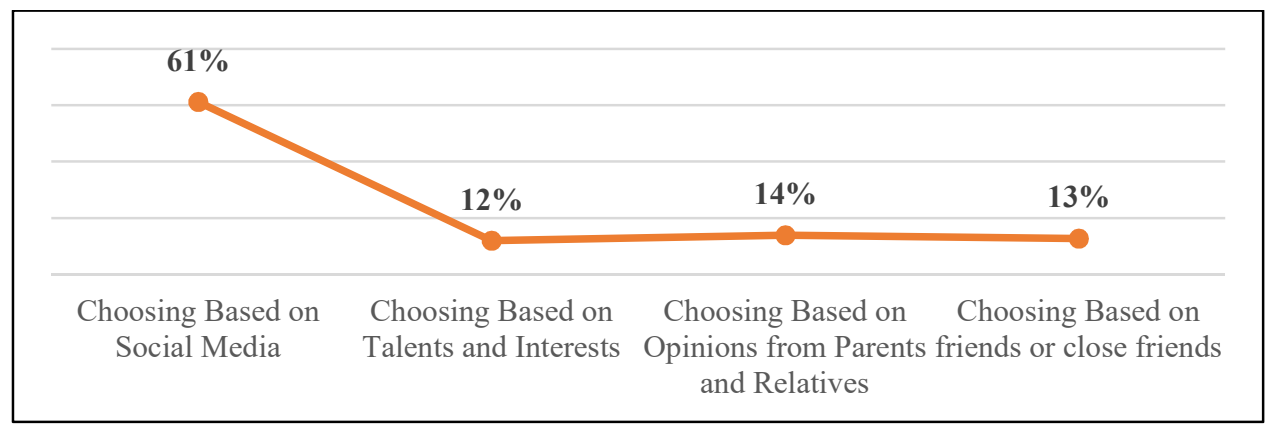

Figure 1.Survey results of student career selection preferences 
Based on figure 1 , it is known that the majority of students who choose social media as their career choice preferences tend to use information that is directly or not directly related to their career choices. This means that other information, even if it is not directly related to his career choice, is still used to consider what their career choices are. Therefore, it is necessary to provide adequate information, especially related to market needs for labor through social media [12]. Social media which currently become a lifestyle have influencedvarious sectors of life, including career decision making [4]. It is not surprising that any information provided by social media is sometimes swallowed up directly for making decisions. Cognitively, the information obtained will definitely influence students' sell efficacy in making career decisions [17]. The results of the study indicate that there is a tendency for someone to use social media services to choose careers that is prone to be unattached to strict rules such as working for the government [18].

The second majority choice of career choice preferences is based on the advice and or directivefrom parents and relatives. This supportsthe previous research which revealed the influence of the social structure in which students live in their orientation and career decision making [19]. This indirectly legitimizes that despite the amount of the contribution, family and their closest people have certain influence in the students'decision-making process and career development. In general, this study also supports Social Cognitive Career Theory (SCCT) which describes the influence of social environment in providing information that affects career decision making process. Other data shows that $6 \%$ of students choose careers by obtaining career information from their closest friends. This is related to environmental expectations of student career choices including their social environment [20].

Every generation (senior generation, generation $\mathrm{X}$ and generation $\mathrm{Y}$ ) has different career choice preferences. Generation $\mathrm{X}$ and $\mathrm{Y}$ tend to choose career organizations that are in line with their career aspirations while the senior generation tends to be pragmatic by relying on comfortable choices and making themselves income-safe [21]. Students who become the respondents are the representation of generation $\mathrm{Z}$ who use technology as a lifestyle. They have the tendency to be adventures in choosing a career until they find a place that feels the most comfortable for their existence (multi-trial careers). This also explains the occurrence of career coping processes as a result of social interaction in a narrow (family) and semi-broad environment (school and society) [22]. In other situations, students' career awareness takes part in encouraging the process of further career exploration in the framework of career planning and the continuing career selection process [23].

The use of the internet as a medium to help make career decisions is actually not new. Internet-based Making Better Career Decisions (MBCD) has previously been developed to help people plan their careers [24]. The majority of them have made their career decisionmaking processes, learned about additional factors that must be considered and preferences related to their careers, and understood the quality of the list of 'promising' career alternatives presented [25]. Then Career HOPES which helped facilitate the career exploration process on an internet-based basis which results in greater benefits obtained through interaction with the program was developed[26]. This shows that the internet is very potential to be used as a medium of interaction for career planners to help people make choices and career decisions that are important for their lives. The tendency of students to use the internet as a supporting media for self-study is very high, reaching $69.2 \%$, which actually justifies the results of this study which revealed that $61 \%$ of students use social media to surf their careers [27].

Career selection process carried out by students after exploring through social media must still get assistance from a counselor. Extensive information about career counseling services allows students to take advantage of these services to obtain more objective and 
comprehensive information in understanding themselves and exploring their career opportunities. In addition,the support by the use of tests in career guidance will greatly assist the investigation process of their career preferences and diagnose obstacles to career development that may be experienced by students and get beneficial information about students' self-potential[28].Future researches are expected to reveal more interesting facts about the use of social media as a tool to take career decisions as reinforcement of the results of this survey. Bias by increasing the diversity of respondents or the quantity of respondents is higher, which is certainly expected by the development of interactive programs based on social media that are often used by Indonesian student community.Hence, counselors must be technologically literate and capableof utilizing technology, especially social media to open career-counseling services the main goal of which is to achieve a happy life for students through appropriate career selection and media that are very close to students.

\section{Conclusion}

From the results of the conducted research, it can be concluded that social media have an important role in providing direct and indirectinformation related to students'career aspiration. It shows the high possibility of social media as the mainpreferenceand choice in career choices that need to be facilitated by counselors through mentoring. Thus, students are able tofilter out the correct and objective information fromthe deviational and subjective one, and obtain useful information from social media such as Facebook, Instagram, Twitter, YouTube, WhatsApp and the others. The implication is that counselors are expected to be able to design long-term programs for the use of internet technology in general and specifically social media in providing a broad space to interact with students to discuss the process of students' selfunderstanding, understand the aspirations of the surrounding environment, plan students'career, and choose the right career choice. In general, this research will be better with a larger sample by consideringvarious cultural diversity, social structures and quality of schools that isreflected not only in the accreditation score but also in the academic quality that students have to obtain a further picture of preferences in choosing a career. The suggestion for the next researchers is definitely to fix these deficiencies to perfect this research.

\section{Reference}

[1] I. Istirahayu, D. Mayasari, S. Fitriyadi, and Z. Damayanti, "Bimbingan Karir Terhadap Pemilihan Studi Lanjut Siswa Kelas XII,” J. Bimbing. dan Konseling Terap., vol. 02, no. 01, pp. 32-40, 2018.

[2] J. D. Krumboltz, A. M. Mitchell, and G. B. Jones, "A Social Learning Theory of Career Selection," Couns. Psychol., vol. 6, no. 1, pp. 71-81, 1976.

[3] E. Goldsberry, K. C. Gehrt, H. Sun, and S. Shim, "Career preference for retail formats among college students: A socialization perspective," Cloth. Text. Res. J., vol. 17, no. 1, pp. 36-46, 1999.

[4] S. Shim, K. Gehrt, and E. Goldsberry, "Socialization-based approach to predicting retail career preference and choice," J. Mark. Educ., vol. 21, no. 1, pp. 14-24, 1999.

[5] R. J. Emmerling and C. Cherniss, "Emotional intelligence and the career choice process.," J. Career Assess., vol. 11, no. 2, pp. 153-167, 2003. 
[6] J. D. Brodzinski, K. A. Goyer, R. F. Scherer, and F. A. Wiebe, "Differentiatig Among Three Measures of Career Preference,” Psychol. Rep., vol. 65, no. 1, pp. 1275-1281, 1989.

[7] K. Clayton, R. D. Wessel, J. McAtee, and W. E. Knight, "KEY Careers: Increasing Retention and Graduation Rates With Career Interventions," J. Career Dev., pp. 1-15, 2018.

[8] A. T. Haryanto, "130 Juta Orang Indonesia Tercatat Aktif di Medsos,” Detik, 2018. [Online]. Available: https://inet.detik.com/cyberlife/d-3912429/130-juta-orangindonesia-tercatat-aktif-di-medsos.

[9] K. Ko and K. N. Jun, "A Comparative Analysis of Job Motivation and Career Preference of Asian Undergraduate Students," Public Pers. Manage., vol. 44, no. 2, pp. 192-213, 2015.

[10]C. D. Evans and A. B. Diekman, "On motivated role selection: Gender beliefs, distant goals, and career interest," Psychol. Women Q., vol. 33, no. 2, pp. 235-249, 2009.

[11]F. Abrahams, R. Jano, and B. van Lill, "Factors Influencing the Career Choice of Undergraduate Students at a Historically Disadvantaged South African University," Ind. High. Educ., vol. 29, no. 3, pp. 209-219, 2015.

[12]P. Mncayi and S. H. Dunga, "Career choice and unemployment length: A study of graduates from a South African university," Ind. High. Educ., vol. 30, no. 6, pp. 413423, 2016.

[13]D. M. Reile and J. Harris-Bowsley, "Using The Internet in Career Planning and Assessment," J. Career Assess., vol. 8, no. 1, pp. 69-84, 2000.

[14]Kementerian Pendidikan dan Kebudayaan, "Jumlah Peserta Didik Per Kabupaten/Kota," Data Referensi Kementerian Pendidikan dan Kebudayaan, 2018. [Online]. Available: http://referensi.data.kemdikbud.go.id/pd_index.php?kode=031900\&level=2.

[15] Kementerian Pendidikan dan Kebudayaan, "Jumlah Satuan Pendidikan Provinsi Jawa Tengah,” Data Referensi Kementerian Pendidikan dan Kebudayaan, 2018. [Online]. Available: http://referensi.data.kemdikbud.go.id/index11.php?kode=031900\&level=2.

[16]E. Zamroni, N. Mahardika, S. Rahardjo, and Masturi, "Dataset Survey Social Media as Career Selection Preference," 2019. [Online]. Available: https://osf.io/bu6dz/.

[17]L. D. Lindley, "Perceived barriers to career development in the context of social cognitive career theory," J. Career Assess., vol. 13, no. 3, pp. 271-287, 2005.

[18]L. Bright, "Is Public Service Motivation a Better Explanation of Nonprofit Career Preferences Than Government Career Preferences?," Public Pers. Manage., vol. 45, no. 4, pp. 405-424, 2016.

[19] S. E. Kaminsky and T. S. Behrend, "Career Choice and Calling: Integrating Calling and Social Cognitive Career Theory," J. Career Assess., vol. 23, no. 3, pp. 383-398, 2015.

[20]Z. Aycan and S. Fikret-Pasa, "Career Choices, Job Selection Criteria, and Leadership Preferences in a Transitional Nation: The Case of Turkey," J. Career Dev., vol. 30, no. 2, pp. 129-143, 2003.

[21]D. Chawla, A. Dokadia, and S. Rai, "Multigenerational Differences in Career Preferences, Reward Preferences and Work Engagement among Indian Employees," Glob. Bus. Rev., vol. 18, no. 1, pp. 181-197, 2017.

[22]K. H. Lee, "Coping with career indecision: Differences between four career choice types," J. Career Dev., vol. 31, no. 4, pp. 279-289, 2005.

[23]D. Lavallee, "Career awareness, career planning, and career transition needs among 
sports coaches," J. Career Dev., vol. 33, no. 1, pp. 66-79, 2006.

[24]I. Gati, T. Kleiman, N. Saka, and A. Zakai, "Perceived benefits of using an Internetbased interactive career planning system," J. Vocat. Behav., vol. 62, pp. 272-286, 2003.

[25]I. Gati, R. Gadassi, and N. Shemesh, "The predictive validity of a computer-assisted career decision-making system :," J. Vocat. Behav., vol. 68, pp. 205-219, 2006.

[26] S. Herman, "Computers in Human Behavior Career HOPES : An Internet-delivered career development intervention," Comput. Human Behav., vol. 26, no. 3, pp. 339-344, 2010.

[27] J. A. Taylor, C. M. Shaw, S. A. Tan, and J. L. Falcone, “Are the kids alright? Review books and the internet as the most common study resources for the general surgery clerkship," Am. J. Surg., pp. 1-5, 2017.

[28]D. S. Osborn and N. Jennifer, "School Counselors' Perceptions of Career Counseling and Career Testing: Preferences, Priorities, and Predictors," J. Career Dev., vol. 31, no. 1, pp. 45-59, 2004. 